\title{
Geodemographic Aspects of Covid-19
}

Aspectos geodemográficos de Covid-19

Aspectos geodemográficos de Covid-19

Les traits géodémographiques de la covid-19

\section{Milen Penerliev and Veselin Petkov}

\section{OpenEdition \\ Journals}

Electronic version

URL: http://journals.openedition.org/espacoeconomia/13444

DOI: 10.4000/espacoeconomia.13444

ISSN: 2317-7837

\section{Publisher}

Núcleo de Pesquisa Espaço \& Economia

\section{Electronic reference}

Milen Penerliev and Veselin Petkov, « Geodemographic Aspects of Covid-19 », Espaço e Economia

[Online], 18 | 2020, Online since 21 April 2020, connection on 20 May 2020. URL : http://

journals.openedition.org/espacoeconomia/13444; DOI : https://doi.org/10.4000/espacoeconomia 13444

This text was automatically generated on 20 May 2020.

(C) NUPEE 


\title{
Geodemographic Aspects of Covid-19
}

\author{
Aspectos geodemográficos de Covid-19 \\ Aspectos geodemográficos de Covid-19 \\ Les traits géodémographiques de la covid-19
}

Milen Penerliev and Veselin Petkov

\section{Introduction}

1 Being a spatial science, geography is called upon to analyze all ongoing processes and phenomena in a three-dimensional geographical space, including the health assessment of the geographical environment and particular diseases that affect the population inhabiting that environment. The structure includes a separate discipline dealing precisely with such topical social issues, known as medical geography.

2 The founder of medical geography was the London physician John Snow (1813-1858). He lived during a worldwide cholera pandemic in the mid-nineteenth century. The city officials could not identify the source of the infection. Snow attempted to come up with a map of fatalities across London. After exploring those locations, he discovered an unusually high accumulation of deaths near a street-pump on Broad Street. Snow came to the conclusion that the water coming from that particular street-pump was the reason why people got sick and the authorities eventually removed it (www.geograf.bg; https://history.framar.bg/). After people stopped drinking from that water source, the number of cholera deaths in London sharply decreased.

3 Today, according to the Big Russian Encyclopedia (https://bigenc.ru), medical geography studies the geographical patterns in the spread of human diseases and pathologies, as well as the impact of geographical environment on the incidence rate and human health. In addition, this branch of social geography examines the spatial features of the natural, social and environmental factors which determine the frequency and nature of the manifestation of individual diseases. 

branches of geography in general. Chistobayev and Semenova (2009) summarize medical geography's interrelations with social sciences, humanities, legal sciences, ecological and geographical sciences, etc.

5 The above clearly highlights the relevance of medical geography as a "tool" for studying and analyzing diseases, their causes and the environment that generates them, thus justifying the direct link between "viruses and geography".

\section{Data And Analysis}

\section{Spatial distribution ${ }^{1}$}

It is still difficult to determine the timing and the exact location of the origin of the coronavirus (Covid-19) pandemic. The first officially reported cases were in the last days of 2019 and came from the city of Wuhan, China. The Western press (The Guardian, etc.) claims that a 55-year-old man was first infected on November 17, 2019. Thereafter, between 1 and 5 new cases were reported daily, and by the first announcement by the Chinese authorities, there had already been over 60 new cases. The Chinese authorities had been hiding this unknown contagious disease for more than a month.

The first case in North America was registered on January 21, 2020, after a US citizen had returned from Wuhan (China) a week earlier.

In Europe, the coronavirus is thought to have appeared simultaneously in Germany and France around February 1, 2020, after some French nationals had returned from the then center of the epidemic - the Chinese city of Wuhan, while one of them carried the infection. In that same time, an employee of a Bavarian firm had been infected after negotiations with Chinese partners which had taken place also in Wuhan. Other sources indicate (Rothe et al., 2020) that the first ill individual in Germany was a German national (diagnosed positively on January 27, 2020) after conducting a business meeting in Munich with a Chinese businessman from Shanghai between January 19-21, 2020. The Chinese businessman is believed to have brought the infection to Germany.

The first case of coronavirus in Australia was registered on January 25, 2020, when a man who had returned earlier from Wuhan was tested positive. The ensuing several new cases within a few days were all of Australian nationals who had returned from Wuhan.

10 On February 11, the World Health Organization (WHO) named the disease Covid-19. The full name was "Severe Acute Respiratory Syndrome Coronavirus 2" or SARS-CoV-2 (https://www.newscientist.com). Its civilian name remained Covid, with a supplement “19", referring to the year of its appearance, hence - Covid-19.

11 In Africa, the first reported case was from 14 February, 2020 in Egypt, when a Chinese national was tested positive.

The first case in South America was registered on February 26 in Sao Paulo (Brazil). The infected individual was a man who had traveled to Lombardy region of Italy (Faria, 2020).

13 The first case in Bulgaria was registered on March 8, 2020.

Espaço e Economia, 18 | 2020 

directly from the "birthplace" of the infection - Wuhan, China, with the exception of South America. Today's dynamic world of mass and relatively inexpensive travelling, communications clearly facilitate the "transport" of infections as well. This conclusion is important because if the Chinese authorities had not concealed the presence of a new infection for nearly a month, the "geography" of Covid-19 would be different, since human migration is a leading geodemographic factor!

\section{Geodemographic characteristics} At the moment, the highest number of reported cases is in the United States - over 560 thousand, while the second place is occupied by Spain - 170 thousand. The third place is currently held by Italy with 156 thousand cases. This is a completely different picture from 2 weeks before, when Italy was the leading country in the world by number of cases. China, the source of the infection, has registered 82160 people with Covid-19 to date (April 13, 2020).

17 The choice of a parameter measuring the mortality rate has triggered some controversy - often, different criteria for such calculations give different results in different countries. In this study we adopt the viewpoint of most scholars, according to whom the mortality rate is the number of fatal outcomes as a percentage of the total number of reported cases (Chen Chien-Jen and others ${ }^{2}$ ). The differences in that aspect, observed between some countries, are most likely due to the different methodology for registering new cases. In countries that perform mass testing of their population, the mortality rate will be lower (e.g. Germany), and in those who test only those seeking medical help (i.e. more severe cases only), it will be higher (e.g. Italy).

Clear demographic variations related to age have been observed in relation to Covid-19 mortality (Figure 1). It is a well-known fact that the infection is more fatal among the population of above-working age. The chart below shows that the probability of a fatal outcome is the highest among patients aged $80+$ years $(14.8 \%)$, followed by those aged between 70 and 79. Among younger patients, the probability of a fatal outcome significantly drops - even in the age group of relatively senior patients aged 60-69, the mortality rate drops to just over $3 \%$, while it is even lower (below 1\%) among patients aged 49 or younger. Today, the current preventive measures include temporal separation of these two large age groups in the overall urban life cycle. 
Figure 1. Covid-19 mortality rate by age groups as of 20 March, 2020

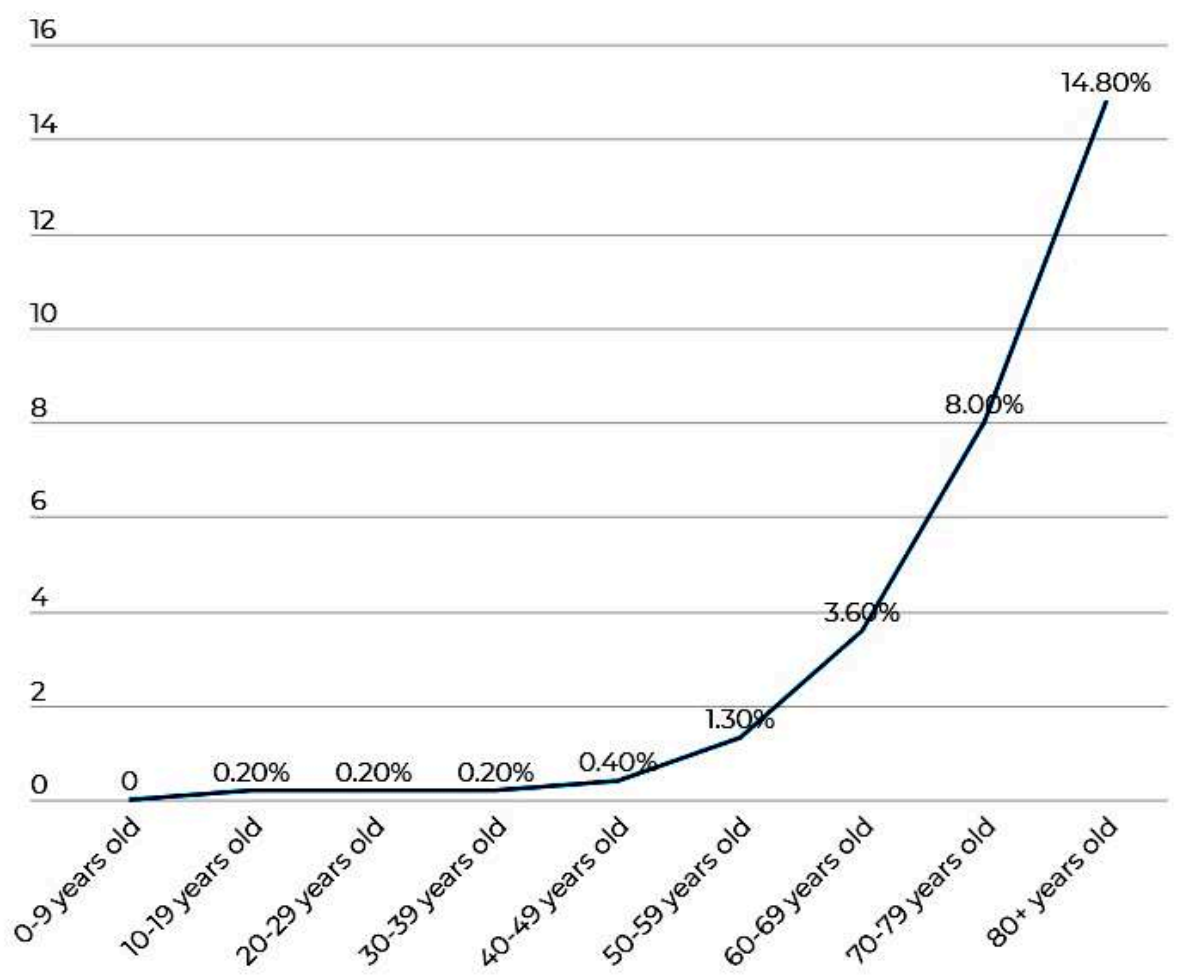

Source: WHO

19 Fatalities also exhibit a clear dependency on gender - the mortality rate among men is twice as that among women: $4.7 \%$ as opposed to $2.8 \%$ (as a share of all registered cases, www.worldometers.info).

Over the past few weeks, data on high mortality rates among the Italian population have been increasingly analyzed in the periodical European Press (sueddeutsche.de, etc.), including in a number of other European countries, such as Bulgaria. Along with purely medical reasons, it has been emphasized on the fact that the high mortality rate is directly dependent on the severely deteriorated age structure of the Italian population. Here we give our "geodemographic reading" of basic population characteristics for selected countries in order to test the validity of such a hypothesis.

Table 1. Covid-19 mortality rate by country (as of April 12, 2020)

\begin{tabular}{|l|l|l|}
\hline Country & Number of deaths & Mortality rate (\%) \\
\hline & 1 & 2 \\
\hline Italy & 19899 & 12.7 \\
\hline Spain & 17489 & 10.3 \\
\hline China & 3341 & 4.1 \\
\hline Germany & 3022 & 2.4 \\
\hline
\end{tabular}




\begin{tabular}{|l|l|l|}
\hline Bulgaria & 32 & 4.6 \\
\hline USA & 22134 & 3.9 \\
\hline
\end{tabular}

SOURCE: www.worldometers.info (12 April, 2020); Column 2: Authors' calculations

21 The table does confirm the conclusions about the high mortality rate in Italy - indeed, in this country the mortality rate is the highest at the moment (April 13, 2020) - 12.7\%. On the other hand, in Germany it is the lowest (among the selected countries in the table) - only $2.4 \%$ of the cases registered have been fatal. Even in the US, which is now a leading pandemic country, there is a relatively low mortality rate. Bulgaria occupies an intermediate position (4.6\%). What are the reasons for that?

The dependence of fatal outcomes on the population age structure is an important geodemographic indicator. The most commonly used indicator is the "average age" of the infected persons. That indicator has already been analyzed and it is proven to be justifying to a large extent the lower mortality rate in Germany, where the average age of the infected remains relatively low - 49, while in France it is 62.5 and in Italy - 62, according to their most recent national reports (Bennhold, 2020). According to Bulgarian authorities, the average age of coronavirus patients in Bulgaria is 48 years (Ministry of Health, April 10). Naturally, other authors too claim that the highly developed healthcare system and mass testing in Germany play a significant role. However, here we are focusing on the geodemographic indicators only.

\section{Intraterritorial geodemographic analysis}

Is it true that the deteriorated age structure is to blame for the high Covid-19 mortality rate in Italy? Along with this question, we will try to answer whether demographic characteristics, such as average density of the population and the total population number, influence the spread of the disease.

To answer this question scientifically, we have made a comparison between selected countries by comparing the most affected administrative units in each country (the administrative unit with the highest number of infected as of April 13, 2020).

The most affected areas in Italy are the regions of Lombardy and Piedmont. As of April 12,2020 , the total number of Covid-19 cases across Italy was 156000 . In both regions, they total 75600 , which is $48.5 \%$ of the total number nationwide, i.e. every second infected person is a resident of one of those two administrative units. However, the region of Lombardy leads with over 59 thousand confirmed cases (35.9\% of all in Italy). Naturally, this difference between the two regions is correlated with their total population (Table 3). Lombardy is home to over 10 million people, out of Italy's total population of 60 million. The population of Piedmont region on the other hand is just over 4 million people (www.statista.com).

The direct connection between the population number and the number of infected is obvious. For the purpose of an adequate comparative analysis, the authors have calculated the coefficient "numbers of infected per 10 thousand people". This would greatly clarify the "picture" of the spatial manifestation of the disease. With regard to Italy, it is evident (Table 2) that the region of Lombardy exhibits values of the indicator twice higher than the national average: 58/10 000 as opposed to 26/10 000. This 
indicates the strong spatial concentration of Covid-19 in Lombardy. Piedmont region, although the second most affected, has a far lower value of the coefficient than Lombardy (39/10 000), (www.citypopulation.de)

Table 2. Demographic data and Covid-19 data for selected countries around the world

\begin{tabular}{|c|c|c|c|c|c|c|}
\hline \multirow{2}{*}{$\begin{array}{l}\text { Country/ } \\
\text { Region//State }\end{array}$} & \multirow{2}{*}{$\begin{array}{l}\text { Total } \\
\text { population } \\
\text { number } \\
\text { (million } \\
\text { people) }\end{array}$} & \multirow{2}{*}{$\begin{array}{l}\text { Average } \\
\text { population } \\
\text { density } \\
\text { (people } / \mathrm{km}^{2} \text { ) }\end{array}$} & \multirow{2}{*}{$\begin{array}{l}\text { Total number } \\
\text { of registered } \\
\text { Covid-19 cases }\end{array}$} & \multirow{2}{*}{$\begin{array}{l}\text { Registered } \\
\text { Covid-19 cases } \\
\text { per } 10000\end{array}$} & \multicolumn{2}{|c|}{$\begin{array}{l}\text { Age structure } \\
\text { (share of the } \\
\text { total population, } \\
\%)\end{array}$} \\
\hline & & & & & $\begin{array}{l}\text { aged } \\
0-17\end{array}$ & aged $65+$ \\
\hline & 1 & 2 & 3 & 4 & 5 & 6 \\
\hline $\begin{array}{l}\text { Italy } \\
\text { Lombardy } \\
\text { Piedmont }\end{array}$ & $\begin{array}{l}\mathbf{6 0 . 1} \\
10.1 \\
4.3\end{array}$ & $\begin{array}{l}200 \\
421.6 \\
171.5\end{array}$ & $\begin{array}{l}156000 \\
59000 \\
16600\end{array}$ & $\begin{array}{l}26 \\
58 \\
39\end{array}$ & $\begin{array}{l}\mathbf{1 6 . 0} \\
16.6 \\
14.5\end{array}$ & $\begin{array}{l}\mathbf{2 2 . 8} \\
22.6 \\
25.8\end{array}$ \\
\hline $\begin{array}{l}\text { Germany } \\
\text { Baden- } \\
\text { Württemberg } \\
\text { Bavaria }\end{array}$ & $\begin{array}{l}80 \\
11 \\
13\end{array}$ & $\begin{array}{l}231 \\
309.7 \\
185.4\end{array}$ & $\begin{array}{l}127000 \\
23938 \\
31773\end{array}$ & $\begin{array}{l}\mathbf{1 6} \\
22 \\
24\end{array}$ & $\begin{array}{l}\mathbf{1 6 . 4} \\
16.9 \\
16.4\end{array}$ & $\begin{array}{l}21.5 \\
20.2 \\
20.4\end{array}$ \\
\hline $\begin{array}{l}\text { USA } \\
\text { New York } \\
\text { New Jersey }\end{array}$ & $\begin{array}{l}328 \\
19 \\
8.8\end{array}$ & $\begin{array}{l}35 \\
159.4 \\
466.3\end{array}$ & $\begin{array}{l}554172 \\
189000 \\
61850\end{array}$ & $\begin{array}{l}17 \\
99 \\
70\end{array}$ & $\begin{array}{l}\mathbf{1 8 . 6} \\
20.8 \\
21.9\end{array}$ & $\begin{array}{l}\mathbf{1 6 . 0} \\
16.4 \\
16.1\end{array}$ \\
\hline $\begin{array}{l}\text { Bulgaria } \\
\text { Sofia-Grad } \\
\text { district }\end{array}$ & $\begin{array}{l}7 \\
1.2\end{array}$ & $\begin{array}{l}63 \\
1030\end{array}$ & $\begin{array}{l}\mathbf{6 8 5} \\
406\end{array}$ & $\begin{array}{l}1 \\
3\end{array}$ & $\begin{array}{l}\mathbf{1 4 . 4} \\
15.3\end{array}$ & $\begin{array}{l}21.3 \\
20.4\end{array}$ \\
\hline
\end{tabular}

SOURCES: various. Column 3: registered cases as of 13 April, 2020; Column 4: Authors' calculations; Demographic data as of 2019.

Similar conclusions can be drawn for the other countries in the studied selection: the most affected provinces in Germany are Bavaria (nearly 32000 cases) and BadenWürttemberg (24 000), which combined make up for $44 \%$ of all reported cases in Germany. This corresponds to the total population of those provinces (Bavaria's population for example is about 13 million). According to the indicator "cases per 10 thousand people" the conclusions about Germany's regions are similar to those about Italy - higher than the national average, although not so significantly - Bavaria has 24 cases per 10 thousand people, compared to $16 / 10000$ on the average in Germany. Although we haven't used data for all the provinces of Germany, it is safe to say that the infection is unevenly distributed over its territory, compared to the other surveyed countries (nearly $50 \%$ of the infected are in the two provinces in discussion).

We let the readers analyze the US data by themselves. The country generally follows the same trends as the ones observed in Germany and Italy. 
view of Bulgaria is interesting - the country is incomparably smaller by population than all other countries in the selection, and yet the value of the indicator "cases per 10 thousand people" is much more favorable - 1/10 000. The concentration of patients is in the capital Sofia (which has the rank of an administrative-territorial district - NUTS 3 level). The incidence rate in the capital is 3 times higher than the national average, while $59 \%$ of all registered cases of Covid-19 in Bulgaria are concentrated there. This makes sense, given that $19 \%$ of the country's population live in Sofia (Petkov, Penerliev, 2020). done more extensively than in Italy and Bulgaria. However, the levels of the studied indicator differ in the three countries, with Germany in the middle. Obviously this cannot be the sole reason for the different results.

31 How exactly the average population density affects the spread of the disease is ambiguous. We are examining this geodemographic aspect, since the hypothesis is that the higher the population density, the easier the virus spreads. But is that actually so?

Two of the selected countries (i.e. the administrative regions surveyed), exhibit inverse relationship between the two indicators: in Germany for example, the province of Bavaria has a lower average population density, yet there are also more total cases of Covid-19 reported. The picture is similar in the USA: in New York State, the average population density is nearly 3 times lower than in New Jersey, yet the incidence rate is 3 times higher. Apparently in those particular regions, the average population density is not a factor in the spatial spread of the pandemic.

The case of Bulgaria and Italy, however, is the opposite: in these two countries there is a clear correlation between population density and incidence rate. The population density in Lombardy is 3 times higher than in Piedmont and the incidence rate respectively is over 3 times higher than in Piedmont. However, a definitive link between the average population density and the spread of the infection cannot be confirmed. For this reason, the authors of this paper suggest a different indicator, which may prove to be more adequate - "average number of cases / $\mathbf{~ k m}^{2}$ ".

We have calculated the proposed indicator only for the administrative units in discussion, so as to estimate the chance (frequency) of a person coming across a carrier of the virus. Although the values obtained are too low, their variations by region show some trends ${ }^{3}$. The indicator has been calculated according to the algorithm for calculation of the average population density, only in this case it is "number of cases / area $\left(\mathrm{km}^{2) "}\right.$ (Table 3).

Table 3. Average density of Covid -19 cases by administrative units

\begin{tabular}{|l|l|l|}
\hline Administrative unit & Area (thousand $\mathrm{km}^{2}$ ) & Number of cases $/ \mathrm{km}^{2}$ \\
\hline & 1 & 2 \\
\hline Lombardy & 23.9 & 2.5 \\
\hline Piedmont & 25.4 & 0.7 \\
\hline Baden-Württemberg & 35.8 & 0.7 \\
\hline
\end{tabular}

Espaço e Economia, 18 | 2020 


\begin{tabular}{|l|l|l|}
\hline Bavaria & 70.7 & 0.5 \\
\hline New York & 122.1 & 1.6 \\
\hline New Jersey & 19.1 & 3.2 \\
\hline Sofia-Grad district & 1.35 & 3.0 \\
\hline
\end{tabular}

SOURCE: Column 1: https://www.citypopulation.de;

Column 2: Author's calculations based on data as of 13 April 2020

Table 3 reveals some interesting trends: the capital of Bulgaria, Sofia, has the status of an administrative district. The concentration of Covid-19 cases is high (see Table 2) and logically the average density of patients is one of the highest $\left(3.0\right.$ patients $/ \mathrm{km}^{2}$ ). Similar is the case of the state of New Jersey (USA) - 3.2 patients $/ \mathrm{km}^{2}$. Another trend is also visible: in the almost identical areas of Lombardy and Piedmont regions of Italy, the difference in the values of the studied indicator is 4 times! This result may indicate that the possibility of further spread of the disease may be higher in Lombardy, given the high values of the discussed indicator there, which is likely to lead to a longer temporal manifestation of the infection.

The proposed indicator can be used for smaller areas as well (cities, agglomerations). The city of New York alone (not the entire state) concentrates more than 100000 of the total of 189000 cases in the whole state of New York (www.citypopulation.de). Calculated on the basis of the New York City metropolitan area only $\left(738 \mathrm{~km}^{2}\right)$ the indicator amounts to 135.5 cases $/ \mathrm{km}^{2}$ ! The chance of coming across an infected person in that case is multiple times higher than in any other area examined in this paper. It is our belief, that when the values of the discussed indicator start to decrease, the "peak" of the infection is likely to have been passed.

And now the main question: does the age structure of the population matter for the Covid-19 incidence rate?

It has become clear that the elderly are much more prone to complications from the disease. As it was already mentioned, the mortality rate in this age group is considerably higher. A number of publications claim that the high mortality rate in Italy is due to its aging population. Table 2 provides data on the age structure of the countries in discussion. The population aged $65+$ in Italy accounts for $22.8 \%$ of the total, in Germany $-21.5 \%$ and Bulgaria $-21.3 \%$, or the shares are quite similar. We believe that a difference of just over 1 point percentage points could not have a significant impact on the extremely high mortality rate in Italy (see Table 1 ). In the US, the demographic situation in terms of population age structure is much more favorable. However, the mortality rates are higher than those in Germany and Bulgaria, where the age structure of the population is worse. The intraregional review also shows similar trends: Piedmont region of Italy has the worst age structure of all the administrative units examined in the paper - the population aged $65+$ accounts for $26 \%$ of the total. The mortality data by region in Italy shows varying trends (Figure 2). It can be seen that the region with the worst age structure comes in third place by total Covid-19 fatalities in Italy (just over 1600 deaths), while Lombardy is leading, followed by EmiliaRomagna. The region of Lombardy (according to the data in Table 2) exhibits an even better age structure of the population compared to the national average. However, 
Covid-19 mortality is the highest in Lombardy, with more than 10500 fatalities as of April 11, 2020, or 5 times higher than in Piedmont region.

Figure 2. Number of deaths caused by Covid-19 in Italy by regions (as of April 11, 2020)

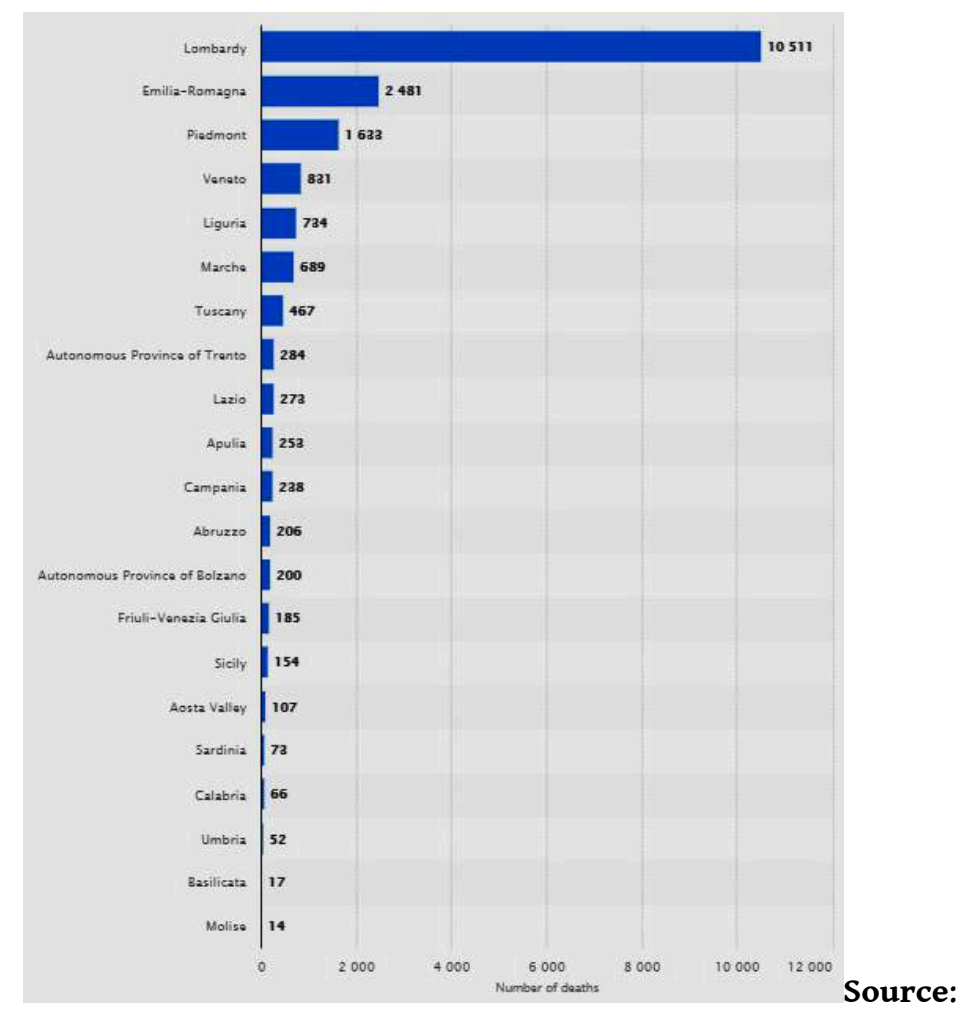

www.statista.com

In the state of New York, with its much better age structure of the population, as of April 10, 2020, there have had been registered over 6000 Covid-19-related fatalities (statista.com), or 32 deaths per 100000 residents, which is much higher than in Piedmont region.

Considering these indicative statements, the authors of this paper strongly believe that the hypothesis for any link between the severely deteriorated age structure in Italy and the high mortality rate in that country is unsubstantiated.

\section{Final considerations}

The analysis performed in this paper is based mostly on demographic indicators such as average age of the population, total population number, average population density, age structure, average density of Covid-19 cases, etc. Given the limited volume of the chapter, other possible indicators were not analyzed. In summary, we need to make the following important statement: geography, with its modern branches such as medical geography, together with the use of commonly accepted demographic indicators (and not only), is a science that presents and analyzes a particular process (disease, pandemic) largely in its spatial aspect. It is clear that geographical analyses dispel a number of myths regarding certain hypotheses. We can summarize the findings of the current study as follows:

There is a direct connection between the average age of the infected persons and the fatal outcome probability 
It is impossible at this stage to confirm the correlation between the average population density and the number of Covid-19 cases in a given area.

44 There is lack of correlation between the age structure of the population and the number of Covid-19-related deaths in Italy.

Although Bulgaria is in a demographic crisis (in all its manifestations), it has far more favorable values of Covid-19-related indicators.

There is a direct correlation between the total population number and the number of Covid-19 cases in a given area.

The average density of patients gives a new look at the spatial spread of the infection.

\section{BIBLIOGRAPHY}

BURGASOV S. P. Golyama meditsinska entsiklopedia (v 30 toma), Izdatelstvo „Savetska entsiklopedia“, 1982, Moskva, s. 528 (in russian).

BENNHOLD, K. A German Exception? Why the Country's Coronavirus Death Rate Is Low, New York Times (https://www.nytimes.com/2020/04/04/world/europe/germany-coronavirus-death-rate, 14.04.2020).

CHISTOBAEV, A. I., Z. A. Semënova, Meditsinskaya geografia v sisteme nauk, vestnik Sankt Peterburgskogo universiteta, Ser. 7, Vыр. 4, 2009 (in russian).

ROTHE Et al, Transmission of 2019-nCoV Infection from an Asymptomatic Contact in Germany, The New England Journal of Medicine, 5.03.2020.

ROSANO, Al., A;. BELLA, A., F. GESUALDO et al. Investigating the impact of influenza on excess mortality in all ages in Italy during recent seasons (2013/14-2016/17 seasons), International Journal of Infectious DiseasesVolume 88, November 2019, p. 127-134.

FARIA et al. First cases of coronavirus disease (COVID-19) in Brazil, South America (2 genomes, 3rd March 2020), (http://virological.org/, 19.03.2020).

PENERLIEV, M. ; PETKOV, V. 2020. Geography of people, settlements and region in Bulgaria, Incoma, Shumen.

PENERLIEV, M. ; PETKOV, V. Covid - 19: Initial Geographical Analysis, Journal SocioBrains, issue 68, april 2020, p. 55-66 (www.sociobrains.com).

www.geograf.bg;

https://history.framar.bg;

www.worldometers.info;

www.statista.com;

www.citypopulation.de;

https://coronavirus.bg/bg/news/103 


\section{NOTES}

1. The case review is on Penerliev, M. V.Petkov, Covid - 19: Initial Geographical Analysis, Journal SocioBrains, issue 68, april 2020, p. 55-66 (www.sociobrains.com).

2. Other formulas for calculating the mortality rate are used as well, but the current study does not aim to focus more on that aspect. For more information see Ghani, A.C. et al. Methods for Estimating the Case Fatality Ratio for a Novel, Emerging Infectious Disease, American Journal of epidemiology, volume 162, Issue 5, 2005

3. this indicator varies over time (there are both recovered and newly infected). It may be higher due to the fact that there are undetected cases.

\section{ABSTRACTS}

The paper aims to address some of the major issues facing the pandemic development of Covid-19 from a geodemographic point of view. As at the time this paper was being prepared, the pandemic was still "raging" in much of Europe and North America, only intermediate - but nonetheless - official data have been used and analyzed in the study. Some relations between the population and its demographic structures such as gender, age, average population density, total population number, etc. have been considered in relation to the observed trends in the spatial distribution of the coronavirus. The suggested conclusions may prove to be subject of reconsideration, since those were only valid at the time of completion of the study (April 15, 2020).

$\mathrm{O}$ artigo tem como objetivo abordar algumas das principais questões enfrentadas pelo desenvolvimento pandêmico do Covid-19 do ponto de vista geodemográfico. No momento em que este artigo estava sendo preparado, a pandemia ainda estava "em fúria" em grande parte da Europa e América do Norte, apenas dados oficiais intermediários - mas mesmo assim - oficiais foram usados e analisados no estudo. Algumas relações entre a população e suas estruturas demográficas, como sexo, idade, densidade populacional média, número total de populações etc. foram consideradas em relação às tendências observadas na distribuição espacial do coronavírus. As conclusões sugeridas podem vir a ser objeto de reconsideração, uma vez que eram válidas apenas no momento da conclusão do estudo (15 de abril de 2020).

El documento tiene como objetivo abordar algunos de los principales problemas que enfrenta el desarrollo de la pandemia de Covid-19 desde un punto de vista geodemográfico. En el momento en que se estaba preparando este documento, la pandemia todavía estaba "furiosa" en gran parte de Europa y América del Norte, solo se usaron y analizaron datos oficiales intermedios, pero no obstante, en el estudio. Se han considerado algunas relaciones entre la población y sus estructuras demográficas, como el género, la edad, la densidad de población promedio, el número de población total, etc., en relación con las tendencias observadas en la distribución espacial del coronavirus. Las conclusiones sugeridas pueden ser objeto de reconsideración, ya que solo fueron válidas en el momento de la finalización del estudio (15 de abril de 2020).

Sous le point du vue géodémographique, cet article vise à aborder des questions liées à la bataille contre la pandémie de la covid-19. Pendant l'écriture de ce texte, la pandémie était encore « en furie » en grand partie de l'Europe et de l'Amérique du Nord. Ainsi, on n'a décidé d'utiliser que 
des données officielles. En ce qui concerne à la distribution spatiale du coronavirus, on a associé des données relatives au chiffre total de la population, la structure démographique, le sexe et la densité démographique moyenne. Une fois qu'on a fini ce texte le 15 Avril 2020, les conclusions sont encore ouvertes.

INDEX

Mots-clés: Covid-19, géodémographie, les traits de la pandémie, données officielles, population. Palavras-chave: Covid-19, geodemográfica, características da pandemia.

Keywords: Covid-19, geodemographic, characteristics of the pandemic.

Palabras claves: Covid-19, geodemografía, características de la pandemia.

\section{AUTHORS}

\section{MILEN PENERLIEV}

PhD, Full. Prof., "Bishop Konstantin Preslavsky" University of Shumen”, Faculty of Natural Sciences, Department of “Geography”, Shumen, Bulgaria. E-mail: penerliev@yahoo.com.

\section{VESELIN PETKOV}

PhD, University of Shumen "Bishop Konstantin Preslavski”, Bulgaria. E-mail:

Veselin_9003@abv.bg. 